DOI: $10.1590 / 1809-6891 v 15 i 28726$

\title{
FACTORS AFFECTING HEAT TOLERANCE IN CROSSBRED CATTLE IN CENTRAL BRAZIL
}

\author{
Concepta Margaret McManus ${ }^{1}$, Helder Louvandini ${ }^{2}$, Tiago Prado Paim ${ }^{3}$, Flávia Cristina \\ PAUlA E SILVA ${ }^{4}$, FRANCISCO ERNESTO MORENO BERNAL ${ }^{1}$
}

\begin{abstract}
${ }^{1}$ Professores Doutores da Universidade de Brasilia, Brasilia, DF, Brasil. concepta@ unb.br
${ }^{2}$ Professor Doutor do Centro de Energia Nuclear na Agricultura, USP, Piracicabe, SP, Brasil

${ }^{3}$ Medico Veterinário Mestre do Instituto Federal Goiano, Iporá, GO, Brasil.

${ }^{4}$ Aluna de Pós-Doutorado da Universidade de Brasilia, Brasília DF, Brasil
\end{abstract}

\section{ABSTRACT}

This study compared the adaptation traits in common crosses of crossbred dairy cattle in central Brazil. Twenty animals of each of three genetic groups were used: zebu (Bos indicus), Simmental $\mathrm{x}$ Zebu (SZ) and Holstein $\mathrm{x}$ Zebu (HZ). The test measured variations in rectal temperature $(\mathrm{RT})$, respiration rate $(\mathrm{RR})$ and heart rate (HR) of animals in the shade and after exposure to the sun, as well as mean daily milk production throughout the lactation period. The procedure was repeated three times. There were significant interactions between test group and genetic group for the traits investigated and the correlations among traits were low. The RR of the crossbred groups may be controlling body temperature in such a way as not to cause an increase in RT. Milk production influenced $\mathrm{RR}$ in crossbred cows exposed to the sun, confirming their poorer adaptation in comparison with zebu cows. We observed that the adaptation can be measured in terms of production within the same genetic group. In conclusion, the crosses with European breeds produced more milk than zebu, although they were influenced by heat/solar radiation.

KEYWORDS: dairy cattle, heart rate, milk production, rectal temperature, respiration rate.

\section{FATORES QUE AFETAM A TOLERÂNCIA AO CALOR EM GADO MESTIÇO NO BRASIL CENTRAL}

\section{RESUMO}

Este estudo comparou as características de adaptação em cruzamentos comuns de gado leiteiro mestiços no Brasil central. Foram utilizados vinte animais de cada um dos três grupos genéticos: Zebu (Bos indicus), Simental $\mathrm{x}$ Zebu (SZ) e Holandês x Zebu (HZ). Foi medida a variação da temperatura retal (RT), frequência respiratória (RR) e frequência cardíaca (HR) dos animais à sombra e depois da exposição ao sol, bem como a produção média diária de leite durante todo o período de lactação. O procedimento foi repetido três vezes. Houve interações significativas entre o grupo teste e grupo genético para as características investigadas e as correlações entre as características foram baixas. A RR dos grupos mestiços parece controlar a temperatura corporal de maneira que não cause um aumento na RT. A produção de leite influenciou RR em vacas mestiças expostas ao sol, o que confirma a adaptação mais pobre em comparação com vacas zebuínas. Observou-se que a adaptação pode ser medida em termos de produção dentro do mesmo grupo genético. Em conclusão, os cruzamentos com raças europeias produziram mais leite do que o zebu, apesar de terem sido influenciados pelo calor da radiação / solar.

PALAVRAS-CHAVE: frequência cardíaca, frequência respiratória, gado leiteiro, temperatura retal, produção de leite. 


\section{INTRODUCTION}

Most of the genetic resources used for the improvement of the Brazilian dairy cattle originates from temperate countries (North America and Europe), where the production and market circumstances are in general different from those prevailing in Brazil. Holstein is the main specialized dairy breed imported in Brazil. Zebu breeds are characterized by rusticity, thermotolerance, resistance to parasites as well as capacity to use high roughage diets, characteristics of great importance in tropical dairy production systems ${ }^{1}$.

The Brazilian Cerrado show great potential for the development of national agriculture. Most of the herd in this region is represented by a mixture of breeds, where the most prominent are the zebu, mainly represented by crosses between Gyr and Nellore (Bos indicus). European cattle (Bos taurus) for dairy production in Brazil are mainly represented by crosses with the Holstein and Simmental. The crosses of specialized dairy breeds with Zebu are practiced widely by milk producers in the Southeast, which for more than 70 years have been replacing the original local cattle by a predominantly mixed breed herd. This is presumably to combine production and adaptation $^{2,3}$.

The tropics have the hottest climates on the planet and animal production is affected by the environment. Müller ${ }^{4}$ stated that climatic factors, such as temperature, relative humidity, wind speed and solar radiation, may cause stress. These factors interact causing greater or lesser degrees of stress thereby affecting growth, milk production, reproductive success, etc. Thus, heat stress is one of the main factors involved in the reduction of productivity and animal development, as the lack of thermal comfort means that the animal looks for ways of losing heat. This involves a series of adaptations and for cattle production in hot regions, the respiratory, circulatory, excretory, nervous, endocrine, and enzymatic system have shown to be important in determining the tolerance of each breed to their environment ${ }^{5,}{ }^{6}$. Adapted animals are characterized by the ability to produce well in average environmental conditions and climatic extremes, and show maintenance or minimal reduction in productive performance exhibiting high reproductive efficiency, longevity and low mortality rate during exposure to stress ${ }^{7}$.

The present work aimed to investigate the effect of heat stress in crosses between common breeds in Central Brazil.

\section{MATERIALS AND METHODS}

Twenty Zebu animals (Bos indicus), 20 Simmental x Zebu animals (SZ) and 20 Holstein $x$ Zebu animals (HZ) were used. The zebu dams were animals common to the Central Brazil region, mainly represented by Nellore and Gyr, and most of the crosses between them were chosen from a pool of dams, not for their genetic potential, but according to their adaptation to the milking system. All animals were vaccinated against Foot and Mouth Disease, Blackleg and Gas gangrene. Ectoparasites were treated sporadically with phosphorous based products.

The animals were put to graze in areas that, according to a visual assessment, presented the best conditions. Stocking rate employed approached $1 \mathrm{AU} / \mathrm{ha}$. In the dry season, the animal feed was supplemented with a mixture of chopped cane with urea (1\%). A mineral mixture with macro and micro minerals was offered ad libitum to the animals. Cultivated pastures of Brachiaria decumbens, Brachiaria ruziziensis, Brachiaria brizantha Palisade, and Andropogon gayanus C.V. Planaltina as well as pastures naturally formed by Melinis menutiflora Hyparhenia rufa were used.

After the first milking in the morning, dams and calves were taken to pasture. Calves older than three months did not remain with their dams, but were sent to pastures for calves only. All these animals returned in the afternoon. All calves were separated from their dams for the second milking. Milk recording was carried out every 14 days.

The methodology used to test heat tolerance consisted of measuring the variation of rectal temperature (RT), respiratory rate (RR) and heart rate (HR) of the animals, throughout the day. The animals were divided in two groups: 1) a control group, which remained fulltime in the shade, and 2) an experimental group that was subjected to heat stress. Both groups had an equal number of randomly selected animals. Heart and 
breathing rates were measured in 30 seconds and the results presented in frequency per minute. The experimental group was maintained in the corral after the morning milking (8 am), waterless. During this period, RT, RR and HR were measured. The animals were maintained under the sun, and after 5 hours of exposure the second measurement was taken at $1 \mathrm{pm}$. The meteorological measurements included relative humidity and temperature every hour, from 7 am to $6 \mathrm{pm}$. The temperatures were taken in the shade $\left(23.8{ }^{\circ} \mathrm{C}\right)$ and in the sun $\left(30.3^{\circ} \mathrm{C}\right)$. On the next day, the control group became the experimental group. The procedure was repeated 3 times.

The mathematical model used was:

$\mathbf{Y}_{\mathrm{ijklmn}}=\boldsymbol{\mu}+\mathbf{C}_{\mathrm{i}}+\mathbf{A}_{\mathrm{j}}+\mathbf{D}_{\mathrm{k}}+\mathbf{T}_{\mathrm{l}}+\mathbf{R}_{\mathrm{m}}+\mathbf{R} \mathbf{T}_{\mathrm{lm}}+\mathbf{e}_{\mathrm{ijk} \mathrm{kmn}}$

Where: $Y_{i j k l m n}=$ observation on the individual $l$;

$\mu=$ constant;

$C_{i}=$ effect of the group of animals, $\mathrm{C}_{\mathrm{i}} \sim \operatorname{NID}(0$,

$\left.\sigma^{2}{ }_{c}\right)$

$\mathrm{A}_{\mathrm{j}}=$ effect of animal within group, $\mathrm{A}_{\mathrm{i}} \sim \operatorname{NID}(0$, $\sigma_{\mathrm{A}}^{2}$ );

$\mathrm{D}_{\mathrm{k}}=$ fixed effect of the day, $k=1,2$ ou 3 ;

$\mathrm{T}_{1}=$ fixed effect of treatment, $l=$ sun or shade;

$\mathrm{R}_{\mathrm{m}}=$ fixed effect of genetic group, $m=$ Zebu, Holstein x Zebu or Simmental x Zebu;

$\mathrm{TR}_{\mathrm{Im}}=$ interaction of genetic group and treatment; $e_{i j k l}=$ random error associated with each observation, assumed to be normally distributed and independent with mean zero and variance $\sigma^{2}$.

The weight of the animal, stage of lactation as well as measurements of body length, height and heart girth were included as covariate (linear and quadratic), but were not significant and so removed from the model. Milk production was included as a linear covariate.

Correlations $(r)$ were calculated as:

$$
r=\frac{\operatorname{cov}(X, Y)}{\sqrt{\operatorname{var}(X) \operatorname{var}(Y)}}
$$

Where: $\operatorname{cov}(\mathrm{X}, \mathrm{Y})=$ covariance between variable $\mathrm{X}$ and variable $\mathrm{Y}, \operatorname{var}(\mathrm{X})$ or $\operatorname{var}(\mathrm{Y})=$ variance of traits $\mathrm{X}$ and $\mathrm{Y}$.

Principal components were used to transform the set of $\mathrm{v}$ variables in a new set, which is a linear function of the original functions and independent of each other. These are used to reduce the number of variables and to detect the relationship between them. After standardization, multivariate analyses were carried out using the Statistical Analysis System, SAS ${ }^{8}$.

\section{RESULTS AND DISCUSSION}

According to studies by Barbosa and Silva ${ }^{9}$, heat stress is caused by a combination of environmental conditions because the effective ambient temperature is higher than the comfort zone of the animal. The four elements that most affect environmental temperature are: air temperature, air humidity, radiation and wind speed. The exact combination of these elements which initiate heat stress is difficult if not impossible to specify. A given combination may be favorable or unfavorable, depending on the animal and the particular conditions in which it finds itself.

Table 1 shows rectal temperature (RT), heart rate (HR) respiratory rate (RR) and milk production in crossbred cattle. We observed low variability. RR has a high coefficient of variation as does milk production. These averages are of the same order when compared with those of European animals in cold weather, HR 60-80 beats per minute, RT between 38.5 to $39.5^{\circ} \mathrm{C}$, according to Blood et al. ${ }^{10}$ and between 24-50 RR per minute, according to Swenson and Reece ${ }^{11}$. RR is the first physiological measure that increases when the animal undergoes heat stress or exercise, showing greater variation than other physiological measures such as rectal temperature, agreeing with McManus et al. ${ }^{6}$, who studied heat tolerance in local cattle breeds in the same region. Simmental cross cattle were significantly larger than the other two breeds studied.

The genetic group was significant for all parameters (Table 2), and milk production also influenced RR. A significant interaction between treatment and genetic group was seen for all characteristics, except HR. This means that the breeds responded differently in the shade and in the sun.

Table 3 shows that Zebu animals had the lowest RT and the highest HR, which might be due to the fact that this genetic group is more nervous and show higher reactivity to handling. At the same time, Zebu had the lowest RR, especially in the shade. As expected, Zebu animals were more tolerant in terms of heat stress ${ }^{6}$. There was no difference between the two European crosses in terms of adaptation. The RR was seen to control body temperature in an efficient manner without causing an increase in RT under the environmental conditions found in this experiment. Kellaway and Colditz $^{12}$ found that the RR and RT in pure breed 
Bos taurus animals were significantly higher when compared to crossbred Holstein-Zebu and their agreeing with the findings in this study, indicating water intake was also higher in conditions of stress, the crosses can adapt well to stressful conditions in Brazil.

Table 1. Summary of data on heat tolerance in crossbred cattle

\begin{tabular}{lccc}
\hline & Mean & CV & SD \\
\hline Rectal temperature & 38.41 & 0.82 & 0.32 \\
Heart rate (beats/min) & 67.24 & 12.02 & 8.08 \\
Milk production (Kg/day) & 4.26 & 25.85 & 1.63 \\
Respiratory rate (breaths/min) & 25.70 & 23.27 & 6.17 \\
\hline & $\mathrm{HZ}$ & $\mathrm{SZ}$ & $\mathrm{Z}$ \\
\hline Height $(\mathrm{cm})$ & $128.8 \mathrm{a}$ & $131.1 \mathrm{~b}$ & $128.3 \mathrm{a}$ \\
Length $(\mathrm{cm})$ & $136.4 \mathrm{a}$ & $137.7 \mathrm{a}$ & $136.6 \mathrm{a}$ \\
Chest Girth $(\mathrm{cm})$ & $173.1 \mathrm{a}$ & $181.1 \mathrm{~b}$ & $172.6 \mathrm{a}$ \\
Milk Yield $(\mathrm{kg})$ & $4.78 \mathrm{a}$ & $4.75 \mathrm{a}$ & $3.22 \mathrm{~b}$ \\
\hline
\end{tabular}

$\mathrm{Cv}$ - coefficient of variation, SD - standard deviation. Numbers in the same line followed by different letters are significantly different $(\mathrm{P}<0.05)$

Table 2. Significance levels for the factors that affect the characteristics of heat tolerance in crossbred cattle

\begin{tabular}{lccc}
\hline & RT & HR & RR \\
\hline Animal within genetic group & $* *$ & $* *$ & $* *$ \\
Environment (Sun/shade) & NS & NS & $* *$ \\
Genetic group & $*$ & $* *$ & $* *$ \\
Environment $*$ genetic group & $\mathrm{NS}$ & $*$ & $* *$ \\
Milk production & $\mathrm{NS}$ & $\mathrm{NS}$ & $*$ \\
\hline
\end{tabular}

RT - rectal temperature; HR - heart rate per minute; RR - respiratory rate per minute; NS - not significant. * P <0.05, ** P <0.01.

Table 3. Least square means for heat tolerance by treatment and genetic group in crossbred cattle

\begin{tabular}{lcccc}
\hline Treatment & Group & RT & HR & RR \\
\hline Sun & HZ & $38.44^{\mathrm{b}}$ & $67.35^{\mathrm{a}}$ & $27.37^{\mathrm{a}}$ \\
Shade & HZ & $38.41^{\mathrm{b}}$ & $66.71^{\mathrm{a}}$ & $24.48^{\mathrm{b}}$ \\
Sun & SZ & $38.49^{\mathrm{b}}$ & $65.97^{\mathrm{a}}$ & $27.63^{\mathrm{a}}$ \\
Shade & SZ & $38.43^{\mathrm{b}}$ & $64.84^{\mathrm{a}}$ & $24.45^{\mathrm{b}}$ \\
Sun & $\mathrm{Z}$ & $38.36^{\mathrm{a}}$ & $70.14^{\mathrm{b}}$ & $23.91^{\mathrm{b}}$ \\
Shade & $\mathrm{Z}$ & $38.30^{\mathrm{a}}$ & $66.97^{\mathrm{a}}$ & $22.55^{\mathrm{c}}$ \\
\hline
\end{tabular}

RT - rectal temperature; HR - heart rate per minute; RR-respiratory rate per minute; HZ - Holstein-Zebu; SZ - Simmental-Zebu; Z Zebu. Numbers in the same column followed by different letters are significantly different $(\mathrm{P}<0.05)$

Table 4 shows the influence of milk production in $\mathrm{HZ}$ and SZ groups are affected when production on $\mathrm{RR}$, highlighting that the milk exposed to the sun, which was expected since the 
European origin means that these are better adapted to cold weather. The influence of milk production appeared only in the animals of European origin when exposed to the sun. This higher milk production may be related to the increased RR, reinforcing the poorer adaptation of these animals. The animals most suited for milk production show less tolerance, in agreement with Mackinnon et al. ${ }^{13}$, who stated that adaptation must be measured in terms of production.

During periods of stress, an animal exposed to the sun has a higher radiating heat load than its metabolic heat production. Studies have shown that rectal temperature and respiratory rate of animals exposed to the sun are significantly higher than those in the shade $e^{6,15}$.

Table 4. Effect of milk production in the respiratory rate

\begin{tabular}{lcc}
\hline Treatment & Group & Milk production \\
\hline Shade & SZ & NS \\
Shade & HZ & NS \\
Shade & $\mathrm{Z}$ & $\mathrm{NS}$ \\
Sun & $\mathrm{SZ}$ & $*$ \\
Sun & $\mathrm{HZ}$ & $* *$ \\
Sun & $\mathrm{Z}$ & $\mathrm{NS}$ \\
\hline
\end{tabular}

HZ - Holstein-Zebu; SZ-Simmental-Zebu; Z - Zebu; NS - not significant. * $\mathrm{P}<0.05$, ** $\mathrm{P}<0.01$.

Table 5 shows that the correlations among traits are low and sometimes negative, indicating that the characteristics do not vary among each other. It also shows that size of the animal is not necessarily linked to milk production. This result differs from Paludo et al. ${ }^{14}$, who found high and positive correlations between traits measured in horses in the same region.

Table 5. Correlations among the characteristics of heat tolerance and production in crossbred dairy cattle

\begin{tabular}{|c|c|c|c|c|c|c|}
\hline \multicolumn{7}{|c|}{ Partial correlations controlling all other variables } \\
\hline & RT & $\mathrm{HR}$ & RR & Milk & Height & Length \\
\hline \multicolumn{7}{|c|}{ Sun } \\
\hline HR & 0.21 & & & & & \\
\hline RR & 0.28 & 0.14 & & & & \\
\hline Milk & 0.19 & -0.23 & 0.00 & & & \\
\hline Height & 0.09 & -0.02 & -0.13 & 0.03 & & \\
\hline Length & -0.15 & 0.08 & -0.05 & 0.11 & 0.55 & \\
\hline Girth & -0.08 & -0.12 & 0.21 & 0.09 & 0.70 & -0.29 \\
\hline \multicolumn{7}{|c|}{ Shade } \\
\hline RT & -0.08 & & & & & \\
\hline $\mathrm{RR}$ & 0.05 & 0.05 & & & & \\
\hline Milk & 0.11 & -0.14 & 0.08 & & & \\
\hline Height & 0.03 & 0.01 & -0.06 & -0.11 & & \\
\hline Length & -0.13 & 0.07 & 0.07 & 0.10 & 0.60 & \\
\hline Girth & 0.02 & -0.04 & 0.08 & 0.15 & 0.71 & -0.32 \\
\hline
\end{tabular}

TR - rectal temperature; HR - heart rate per minute; FR - respiratory rate per minute; ML - average milk. 
For animals exposed to the sun (Figure 1), the first component shows that animals within the same group, which had higher milk production, presented lower indices for body temperature control (HR, RT). This can be summarized in animals with a better adaptation to the environment, and which has increased production, agreeing with Faria ${ }^{15}$. The second component shows a subgroup of animals with higher milk production that has higher RR, RT and $\mathrm{HR}$, while in the shade the second component shows a subgroup of animals with high milk production, RR and RT but low HR. This is expected as animals increase metabolic rate with the production of milk. The first two components explain $52 \%$ of the total variation in the sun and $48 \%$ of variation in the shade.

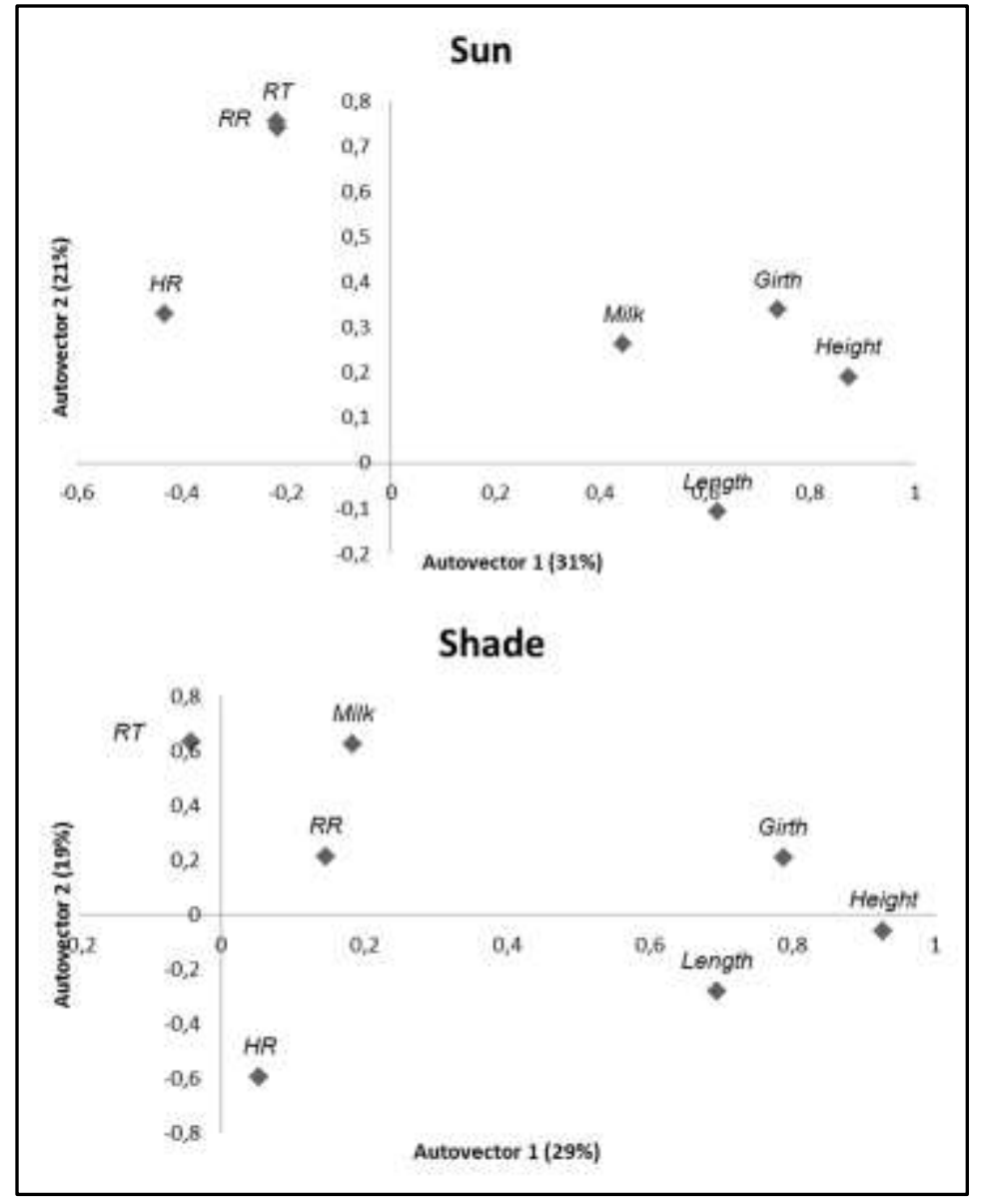

Figure 1. Principal components of characteristics of heat tolerance and milk production in mixed breed cattle in the sun and shade

RT - rectal temperature, HR - heart rate per minute; FR - respiratory rate per minute; ML - average milk.

\section{CONCLUSIONS}

The increase in RR of European crossbred groups can efficiently control body temperature, causing no significant increase in RT. Milk production influenced the RR of cows originated from crosses with European breeds when exposed to the sun, reinforcing the poorer adaptation of these in relation to the zebu group. The heat adaptation can be measured according to the production level of the animal. The animals from crosses with European cattle produce more milk than the zebu cows, although they are more influenced by heat and solar radiation.

\section{ACKNOWLEDGEMENTS}

The authors wish to thank CNPq (Conselho Nacional de Desenvolvimento Científico e Tecnológico) and CNPq/INCT/FAPEMIG INCT Pecuária for scholarships and financial aid. 


\section{REFERENCES}

\section{ABCZ. http://www.abcz.org.br}

2. Madalena FE, Teodoro RL, Lemos AM, Monteiro, JBN, Barbosa RT. Evaluation of strategies for crossbreeding of dairy cattle in Brazil. J Dairy Sci. 1990; 73: 1887-1901.

3. Lemos AM, Teodoro RL, Madalena FE. Estratégias de cruzamentos entre raças leiteiras. Inf Agropec. 1992; 177: 19-22.

4. Müller PB. Bioclimatologia aplicada aos animais domésticos. Porto Alegre: Sulina; 1989. p. 156-192. Portuguese.

5. Perez JH. Parameters for the determination and evaluation of heat stress in dairy cattle in South Africa. J Vet Res. 2000; 67: 263-271.

6. McManus C, Prescott E, Paludo GR, Bianchini E, Louvandini H, Mariante AS. Heat tolerance in naturalized Brazilian cattle breeds. Livest Sci. 2009; 120: 256-264.

7. McManus C, Paludo GR, Louvandini H, Garcia GAS, Egito AA, Mariante AS. Heat tolerance in naturalised cattle in Brazil. Arch Zootec. 2005; 54:453-58.

8. SAS Institute, Version 8, User's Guide, Cary, Indiana,
$295 p p 1999$.

9. Barbosa OR, Silva RG. Índice de conforto térmico para ovinos. Boletim de Indústria Animal. 1995; 52 (1): 29-35.

10. Blood DC, Henderson JA, Radostits OM. Clínica Veterinária. 5nd ed. Rio de Janeiro: Guanabara Koogan; 1983. p. 1121. Portuguese.

11. Swenson MJ, Reece WO. Duke's fisiologia dos animais domésticos. 11nd ed. Rio de Janeiro: Guanabara Koogan; 1996. p. 885. Portuguese.

12. Kellaway RC, Colditz PJ. The effect of heat stress on growth and nitrogen metabolism in Friesian and F1 Brahman x Friesian heifers. Aust J Agr Res. 1975; 26:615-22.

13. Mackinnon MJ, Meyer R, Hetzel DJS. Genetic variation and covariation for growth, parasite resistant and heat tolerance in tropical cattle. Livestock Prod Sci. 1991; 27:105-122.

14. Paludo GR, Melo RQ, Cardoso AG, Mello FP, Moreira M, Fuck BH, McManus C. Efeito do Estresse Térmico e do Exercício sobre Parâmetros Fisiológicos de Cavalos do Exército Brasileiro. Rev Bras Zootecn. 2002; 31:1130-1142.

15. Faria VP. Produção de Leite: Conceitos Básicos. Fealq. 1988; 3:5-12.

Protocolado em: 27 jan. 2010. Aceito em: 22 maio 2014 